\title{
Strategic considerations for establishing a large-scale seaweed industry based on fish feed application: a Norwegian case study
}

\author{
Jan Emblemsvåg ${ }^{1,2}$ (1) $\cdot$ Nina Pereira Kvadsheim ${ }^{1} \cdot$ Jon Halfdanarson ${ }^{1,2} \cdot$ Matthias Koesling $^{3} \cdot$ Bjørn Tore Nystrand ${ }^{4}$. \\ Jan Sunde ${ }^{4}$. Céline Rebours ${ }^{4}$
}

Received: 17 February 2020 / Revised and accepted: 17 August 2020 / Published online: 29 August 2020

(C) The Author(s) 2020

\begin{abstract}
Soy protein concentrate (SPC) is a key ingredient in fish feed and most of it originates from Brazil. However, the Brazilian soy industry has reportedly resulted in significant environmental problems including deforestation. Consequently, new sources for protein are investigated and protein extracted from farmed seaweed is considered an alternative. Therefore, we investigate how seaweed protein product (SPP) can compete against SPC as a protein ingredient for fish feed. The study uses the positioning matrix, cost analyses involving the power law, and uncertainty analysis using Monte Carlo simulations, and key research challenges are identified. The initial finding is that, with the emerging seaweed industry, the cost of producing SPP is too high to be competitive for fish feed applications. To overcome this challenge, two solutions are investigated. First, substantial investments in cultivation and processing infrastructure are needed to accomplish scale, and a break-even scale of 65,000 tonnes is suggested. The second but more promising avenue, preferably in combination with the former, is the extraction of seaweed protein and high-value seaweed components. With mannitol and laminaran as co-products to the SPP, there is a $25-30 \%$ probability of a positive bottom line. Researches on extraction processes are therefore a necessity to maximize the extraction of value-added ingredients. Over time, it is expected that the competitive position of SPP will improve due to the upscaling of the volume of production as well as better biorefinery processes.
\end{abstract}

Keywords Biorefinery $\cdot$ IMTA $\cdot$ Offshore seaweed farm $\cdot$ Harvesting vessel $\cdot$ Seaweed protein product

\section{Introduction}

With an increasing world population and rising living standards, food systems are under increasing pressure and utilizing the oceans has arguably become more important.

Aquaculture is therefore expected to increase in importance, and the global amount of farmed fish is currently at about 80.1 million tonnes (FAO 2019a) out of which approximately 1.4 million tonnes of farmed fish was produced in Norway in 2018 (Statistics Norway 2018). The Norwegian

Jan Emblemsvåg

emblemsvag@yahoo.com

1 Møreforsking Molde AS, Molde, Norway

2 NTNU - Norwegian University of Science and Technology, Trondheim, Norway

3 NIBIO - Norwegian Institute of Bioeconomy Research, Tingvoll, Norway

4 Møreforsking Ålesund AS, Ålesund, Norway aquaculture industry consumes approximately 1.8 and 1.9 million tonnes of fish feed in 2018 and 2019, respectively (Directorate of Fisheries 2020). Additionally, $70 \%$ of the soy imported to Norway is used in fish feed production and salmon feed from Norwegian producers contains about 19\% soy protein (Aas et al. 2019). Unfortunately, approximately $90 \%$ of the soy protein concentrate (SPC) used comes from Brazil (Lundeberg 2018), and soy production in Brazil has come at the large expense of deforestation, and according to Siegle (2009), over the past two decades, 300 million hectares of tropical forests has been felled globally as a result of soybean production.

To meet this challenge, one of the ways to better utilize the oceans is through the production of seaweed for food and feed ingredients. In 2017, seaweed production reached 32.6 million tonnes worldwide (wet weight), of which aquaculture produced 31.7 million tonnes (FAO 2019a). Seaweed farming in Europe is still small-scale (FAO 2019a). Several initiatives and ongoing projects involving both research and commercial actors within the North Atlantic region, particularly in Norway, are aiming at developing cultivation and biorefinery 
processes for various applications (Stévant et al. 2017a). A Norwegian seaweed industry relying on the use of cultivated-seaweed biomass is today emerging and attracting investors from various sectors.

A noticeable link between the current large-scale fish feed industry and the nascent seaweed industry is to utilize the seaweed as ingredients in fish feed. Seaweed extracted protein could potentially reduce the use of SPC used in fish feed, thereby combating deforestation, resource depletion, and significant GHG emissions associated with soybean production (Castanheira and Freire 2013; Raucci et al. 2015). Hence, the environmental case for using more seaweed as protein source at the expense of SPC could be considered. There is today no report on how this change can be achieved in an economically sustainable way. Therefore, the main objective of this paper is to explore how seaweed can become a protein source for fish feed at a scale interesting to the Norwegian aquaculture industry, and for that purpose the following questions are addressed: (1) is there a strategic position where seaweed can compete successfully against SPC, and (2) what will be the economics for such a position?

Replacing SPC with seaweed requires access to a comparable seaweed protein product. In the remainder of the paper, this seaweed product is simply referred to as seaweed protein product (SPP) echoing the FAO standard term "vegetable protein products (VPP)" as a general term used to describe various protein products with different protein contents (FAO 2019b). Further, strategic analyses require the use of reasoning and the integrative literature review's approach. The purpose is "...to create initial and preliminary conceptualizations and theoretical models, rather than review old models. This type of review often requires a more creative collection of data, as the purpose is usually not to cover all articles ever published on the topic but rather to combine perspectives and insights from different fields of research traditions" (Snyder 2019). Our approach is therefore conversational, a method often associated with social sciences and detailed more in "The approach." Since it lacks the stringency of a method, we find it more correct to call it merely an "approach." With this approach, the first step is to understand the market. Then, known physical challenges associated with seaweed farming are discussed in "The challenges of seaweed farming." These two first steps are crucial since they are matters of physical realities and therefore set important ramifications for the economic estimates. In "Strategic analysis of SPP versus SPC," we develop the strategic analysis including a discussion on the strategic implications for the expansion and sustainable establishment of a Norwegian seaweed industry. In "Closure and future work," we relate the results from our analysis to guide future research towards the development of the seaweed industry in Norway.

\section{The approach}

In strategic analyses, the concept of "parity" is crucial. It is also addressed in our study to discuss the competition of SPP versus SPC. According to Porter (1985, p. 13), "parity implies either an identical product offering to competitors, or a different combination of product attributes that is equally preferred by buyers." Thus, comparing prices directly is not meaningful unless the products are identical in relevant aspects. SPP will belong to the low end and large volume part of the market. At the time of our study, the Norwegian seaweed industry is still low volume and caters only to the higher priced food and niche markets.

Large-scale implies commodities as food, feed, and energy as end products with much lower prices compared with the high-end products for human consumption as food, pharmaceuticals, and cosmetical products. Since we are focusing on the lower end of the market, production costs are an important topic to explore to build up a strategy for the development of the seaweed industry in Norway. Our strategic analyses therefore focus on costs, economic value, and unpreventable physical constraints including any other foreseeable limitations on such industry.

SPP as produced today has a much lower protein content than SPC which implies that the actual competitiveness of SPP will rely heavily on its content of other chemical compounds as well. SPP must therefore differentiate itself from SPC to avoid competing directly on price. This evaluation is based on positioning thinking, or the strategy framework of Porter (1985), which belongs to the positioning school in strategy. The positioning matrix in "Positioning SPP from SPC" is therefore a key tool of our study.

Since the seaweed industry is still a nascent industry and the scale contemplated in our case study does not exist yet, we lack data normally required in a typical economic analysis. We will therefore conduct a high-level comparative analysis between SPP and SPC. The losses in accuracy of this approach, compared with a comprehensive economic analysis, advocated by Emblemsvåg (2003), are considered acceptable since the future of SPP as fish feed ingredient depends on its competitiveness to SPC and not on its absolute cost per se but rather the costs and differentiators compared with SPC. Furthermore, both the cost and value are estimated using judgment and simple techniques discussed in detail in "Comparative value chain analysis" because at this early stage of developing a seaweed protein industry, many details are unknown. This also means that some detailed issues related to the production of biological material are ignored as long as they are considered to have negligible impact on the results of our study. Essentially, the paper operates at a conceptual level and the degree of correctness we seek is in the order of magnitudes. 


\section{The challenges of seaweed farming}

Seaweed farming presents challenges that would need to be addressed while performing the strategic analyses of producing SPP as an SPC replacement in fish feed. As SPC, SPP will need to be considered a commodity and large-scale production must be investigated to achieve competitiveness. Harvested seaweed decomposes rapidly and therefore must be processed rapidly (Stévant et al. 2017b; Stévant et al. 2018). In addition, the best areas reported for seaweed farming in Norway are offshore (Broch et al. 2019). However, there is different understanding of the term "offshore" (Buck et al. 2018). As they note, although the term "offshore" suggests a given distance from the shoreline, this does not apply in many cases, especially when exposed conditions may be found within 1-2 km from shore. Buck et al. (2018) therefore propose a definition where "exposed" is the key word. Consequently, in this paper, the size of the farms contemplated in our scenarios is large and we will define offshore as in the oil and gas industry. We therefore define "offshore" as being in the open, fully exposed ocean.

The first of these challenges (i.e., scale) is a premise for the strategy formulation, whereas the latter two-location and logistics - are constraints that a successful strategy must consider. In the following sections, these constraints are discussed.

\section{The location of seaweed farms}

Location is an important issue because concentration of the aquaculture industry has already caused major environmental problems in coastal areas (Holmer 2010), and local communities have increasingly expressed negative opinions about the extent of aquaculture activities in Norway. Fortunately, nutrients are more abundant and in stable quantity offshore, and industrial effectiveness of seaweed production can arguably only be sustained where nutrients are abundant. Industrial effectiveness is an absolute necessity for any commodity, including SPP. Moving offshore is therefore a requirement in the long-term perspective. Offshore locations also escape issues related to area use along the coastline and stakeholder conflicts related to multi-uses of the same area. An operation at a truly industrial scale will consequently only become possible if the technical challenges of offshore production conditions, such as waves, currents, storms, and mooring, can be solved cost effectively.

Norway has sovereignty over its large economic zone of $819,620 \mathrm{~km}^{2}$ with many highly productive "upwelling" areas. This makes the country capable of locating seaweed biomass production offshore. Another option is to exploit possible nutrient surplus in the proximity to salmon farms utilizing the concept of integrated multitrophic aquaculture (IMTA), which is reported to result in higher yield of seaweed biomass
(Handå et al. 2013). The choice of the species of macroalgae is crucial, not only for protein content but also for the length of the harvesting season and when they can be harvested during the year. Production yields for Saccharina latissima, as reported by Broch et al. (2013), are a possible yield of 75 tonnes fresh weight per ha in 4 months (February to June) or about 170 tonnes fresh weight per ha in 10 months (August to June). Thus, seaweed farming on a scale equivalent to that of the current area used for salmon aquaculture (approximately 800 $\mathrm{km}^{2}$ ) will result in about 10 million tonnes wet weight (WW) of seaweed biomass production annually on average. Consequently, the chosen macroalgae has significant design implications for the logistics as discussed next.

\section{The logistics of seaweed farming}

Many strategic as well as logistical challenges are primarily driven by the rapid microbial decomposition of seaweed once harvested (Enriquez et al. 1993). However, storage under controlled conditions, such as the use of refrigerated seawater tanks, results in no significant loss of quality in S. latissima after storage for up to $22 \mathrm{~h}$ (Stévant et al. 2017b). Therefore, we can assume that the seaweed can maintain quality for up to $12-15 \mathrm{~h}$ after harvesting without any treatment. From this, we can directly infer that to maintain quality, seaweed must either be harvested close to the processing facility or treated onboard the vessel if the distance to the processing facility exceeds a few hours by ship.

In Norway, the harvesting season today takes place within a limited time frame (approximately 4-6 weeks for kelp), setting standards for efficient processing strategies (Stévant et al. 2017b). The rapid decay of harvested seaweed creates requirement for a rapid and large capacity to process the biomass to preserve quality. Since we need at least $300,000 \mathrm{t}$ of seaweed for SPP production to be on a scale similar to SPC, we have in reality only one option for such an operation. After harvest, the seaweed must be immediately treated onboard of a ship with sufficient scale and treatment capabilities. The vessels (at least the ones processing the seaweed) must therefore be large enough to take advantage of the economies of scale benefits and the costs of processing equipment.

Thus, the ideal solution is an offshore seaweed farm supported by larger vessels for harvesting and treatment while under transport to a processing facility. Furthermore, due to the short season of harvesting, the vessels need to be multipurpose to facilitate alternative usage the rest of the year. Otherwise, the share of the fixed costs will be unnecessarily high per operational hour or amount harvested. Co-location with offshore fish farms might be beneficial, as argued by Buck and Langan (2017), but this is not included in this study as the technology for this solution will require significant innovations which are not yet developed. 
The only treatment processes that are practical/possible onboard a vessel, are ensilaging (fermentation) or freezing. Drying technologies available at the time of the study would be both too space and time consuming. Ensilage implies use of acids in ships, which normally trigger expensive design solutions due to rules and regulations (especially when considering the case of IMTA and co-production of seaweed on a salmon farm). Thus, freezing on board seems to be the better option and large-scale technology is already today available as it is an established technology in many industries. Freezing also allows for continued storage on land in freezers, which is necessary since the biorefinery will not have the capacity to process everything at once and leveling the production throughout the year is crucial for the profitability of the biorefinery. Given this set-up, the costs of freezing and frozen storage were included in the calculation of the costs.

\section{Strategic analysis of SPP versus SPC}

This analysis consists of a positioning analysis and a comparative analysis of cost and values (see "Positioning SPP from SPC" and "Comparative value chain analysis"). From this, we can argue the best solution in "Discussion-how SPP can outcompete SPC and the research implications."

\section{Positioning SPP from SPC}

Positioning is based on two dimensions for advantage (cost and differentiation) in two scopes: narrow and broad. Following Porter (1985), this results in four competitive positions, or generic strategies, as illustrated in Fig. 1. Note that since SPC is a commodity providing mainly proteins, it has a narrow scope and cost focus as generic strategy. SPC is defined by the FAO (2019b) as vegetable protein products from soy, having more than $65 \%$ and less than $90 \%$ of protein content on a dry weight basis. However, according to Norwegian official import statistics as well as Brazilian SPC

\begin{tabular}{r|c|c|}
\cline { 2 - 3 } Broad & Cost leadership & Differentiation \\
Narrow & Cost focus & Differentiation focus \\
SPC & SPP 2 \\
\hline SPP 1 & Differentiation \\
\cline { 2 - 3 } & Lower cost \\
Competitive advantage
\end{tabular}

Fig. 1 Positioning matrix for the fish feed ingredients industry using SPC as reference product fact sheets, it is evident that SPC used for fish feed in Norway contains less than $65 \%$ protein, most likely in the range of $60-64 \%$. Thus, there is no consensus to rely on, so in this paper we have chosen the FAO definition as the basis of our models and defined SPC as a product with a protein content of $65 \%$.

If SPP does not add any other value than proteins, it will fall into the same position (SPP 1). Nevertheless, SPP contains other ingredients that producers of fish feed may be willing to pay for. As such, SPP has a differentiator over SPC placing SPP into the SPP 2 position. The differentiation will impact the cost structure, and we have identified three major sources of differentiation:

1. Protein content and amino acid profile of SPP versus SPC

2. Ingredient value of SPP versus SPC

3. Environmental impact of SPP versus SPC

These differentiators will now be discussed in subsequent sections. Then, in "Discussion-how SPP can outcompete SPC and the research implications," we discuss whether SPP can improve its position with increased R\&D focus on these differentiators. That means that SPP must achieve parity over SPC or better.

\section{Protein content, amino acid profile, and ingredient value of SPP vs SPC}

Protein-rich macroalgae meal is a promising alternative to soy meal, which is currently the main protein source in the animal feed sector (Lum et al. 2013; Ytrestøyl et al. 2015). Protein quality of a food product is often assessed by its contents and composition of essential amino acids (EAAs) compared with the needs of the animal or, in some cases, by its chemical score. The chemical score equals the lowest value returned when calculating the ratio between each EAA in the food protein and the corresponding EAA in a reference protein proposed by FAO/WHO (see Harper 1981). Proteins of animal source usually have a chemical score of 1.0 , whereas plant proteins normally range from 0.4 to 0.6 . Mæhre et al. (2014) find that the chemical scores of the algae ranged from 0.75 to 1.0, which indicate that the protein quality of algae is superior to most terrestrial plants. Several macroalgae species have a dry matter crude protein content of approximately $50 \%$, which is higher than soybeans (44\%), and the amino acid profile appears to be well balanced and comparable with soybeans (Polprasert 2007).

In fact, the combination of protein content and quality makes algae, especially red algae such as Palmaria palmata, a superior supplement to corn and wheat in fish feed. Due to volume requirements, we have selected $S$. latissima, as our model seaweed species, since it is the only seaweed cultivated in relatively large volumes in Norway. This species has a 
protein content of approximately $10 \%$, according to (Aasen 2018), which is the number we have used in this paper in our analyses. The protein content of soy is, however, much higher (approximately $240 \mathrm{~g} \mathrm{~kg}^{-1}$ ) than that in macroalgae (Mæhre et al. 2014), and direct substitution of SPC will therefore not be feasible.

The combination of beneficial compounds and compounds possessing potential health risks is evident in several of the analyzed species in this project, such as high arsenic and iodine content. Even though the arsenic is organic, and arguably harmless, regulations complicate the utilization. This implies that extraction of single classes of compounds, such as proteins, minerals, and/or fatty acids, for use as ingredients for feed production would be a better approach as this avoids unwanted compounds in the fish feed. Clearly, much research remains to be done in this field. For this paper we therefore focus primarily on a few selected classes of compounds.

\section{Environmental impact as s differentiator for SPP over SPC}

Even though measures have been taken to improve the sustainability of soy production, Lundeberg and Grønlund (2017) argue that a reduction in the use of soy is the only way to stop or reduce deforestation driven by soy production in Brazil. To make this happen, importing countries must become more self-sufficient in producing protein-rich biomass. Protein production based on seaweed can be a good alternative as no agricultural area is needed to grow this type of biomass. The Norwegian and German governments have financially been supporting the Brazilian rainforest initiatives to halt deforestation, but with little results, partly due to the increased need in soybean for their national production. On the contrary, deforestation has increased (Boffey 2019) and it seems more prudent to spend funds at developing a local seaweed industry and thus reduce import of protein for fish feed production.

Another important environmental benefit from cultivating seaweed is the sequestration of nutrients and $\mathrm{CO}_{2}$ from the water (Seghetta et al. 2017). The sequestration of nutrients is even higher when cultivation happens in connection to fish farms as in an IMTA configuration (Beltran et al. 2017), where some of the excess nutrients from the fish farms are incorporated by the algae. When it comes to the processing of the seaweed, the literature focuses on drying technology whereas the investigation of SPP production in this study will focus on freezing technology. Hence, we have yet no reliable estimates concerning the environmental impact of the freezing technology. This is also a challenge concerning costs and will be discussed further in our study.

\section{Comparative value chain analysis}

The next step is to determine the economic cost position of SPP compared with SPC, and then in "Discussion- how SPP can outcompete SPC and the research implications," we evaluate the total competitive situation of SPP compared with SPC. Analyzing the economics of a value chain, which does not yet exist at the scale that the case study considers, is not a straightforward process, and there are several possible approaches other than the one discussed by Emblemsvåg (2003). However, due to the lack of data this approach had to be simplified to an order-of-magnitude accuracy. From the discussions in earlier sections, we performed a number of simplifications as discussed next.

\section{Comparing the costs of SPP value chain to SPC value chain}

To perform the economic analyses, we must make two additional assumptions. First, the scale of the biorefinery for seaweed must be similar to the biorefineries existing today for soy products to achieve economies of scale effects, and second, the processes in the biorefineries are considered equivalent. Hence, we can use the cost data from SPC as an approximation. SPC is sold with low margin and prices have large annual fluctuations of perhaps up to $50 \%$ (Holtermann and Pettersen 2019). We have therefore assumed that it will over time be traded at roughly 1 US\$ per $\mathrm{kg}$ SPC in line with data from Holtermann and Pettersen (2019). This is just an indication of the required cost level of the biorefinery for the SPP to avoid major cost differentials compared with SPC.

Since the value chain in our case study does not yet exist at the scale that the case study needs to consider, we have to construct our data using various sources of information. Our starting point is an analysis, shown in Table 1, that demonstrates that with a 600 ha seaweed farm $\left(6,000,000 \mathrm{~m}^{2}\right)$ the cost for seeding materials, cultivation, and harvesting is about 1.1 EUR kg ${ }^{-1}$ dry matter (Chapman et al. 2014). These estimated costs are still too high compared with SPC, sold typically at $1 \mathrm{US}^{\mathrm{kg}} \mathrm{g}^{-1}$. In addition, in the calculation of a production cost at $1.1 \mathrm{EUR} \mathrm{kg}^{-1}$ dry matter, the biorefinery costs necessary to achieve SPP are still to be added. Furthermore, these data are relatively old but were the only data available at the time of our study. We estimated that with a compounded inflation in Norway since 2014 to year-end 2019 of merely $15 \%$, the age and the source of the data have less impact on the final result than the scaling issues discussed next. Furthermore, between 2014 and the time of this study, the development of seaweed production did not come from increased farm size, but mostly from an increased number of farmers. In addition, the Monte Carlo simulations will largely eliminate the issues concerning the inaccuracy of the data. 
Table 1 Costs for farmed seaweed from genetics through harvesting from the Hortimare case. Source: Chapman et al. (2014)

\begin{tabular}{|c|c|c|c|c|c|}
\hline \multicolumn{3}{|l|}{ Costs: genetics and crop/seedling materials (EUR) } & \multicolumn{3}{|l|}{ Costs: cultivation and harvesting (EUR) } \\
\hline Market size (ha) & 20 & 600 & Market size (ha) & 20 & 600 \\
\hline Yield (dry weight $\mathrm{m}^{-2}$ ) & 1.5 & 2.0 & Yield (dry weight $\mathrm{m}^{-2}$ ) & 1.5 & 2.0 \\
\hline & & & Hatching (reproduction materials) & 0.50 & 0.60 \\
\hline Labor costs production & 1.03 & 0.10 & Labor costs production & 0.52 & 0.32 \\
\hline Overhead management & 0.74 & 0.12 & Overhead management & 1.33 & 0.23 \\
\hline Labor costs associated with R \& D & 0.67 & 0.19 & & & \\
\hline Seasonal labor & 0.08 & 0.03 & Seasonal labor (including boat) & 0.38 & 0.19 \\
\hline Laboratory equipment & 0.22 & 0.02 & Equipment (incl. substrates) & 0.20 & 0.12 \\
\hline Hatchery equipment (Norway) & 0.28 & - & & - & \\
\hline Maintenance & 0.06 & 0.01 & Maintenance & 0.10 & 0.03 \\
\hline General and administrative costs & 0.14 & 0.01 & General and administrative costs & 0.15 & 0.03 \\
\hline Transportation costs (car) & 0.11 & 0.01 & Transportation costs (car) & 0.10 & 0.03 \\
\hline Insurance & 0.02 & 0.00 & Insurance & 0.10 & 0.01 \\
\hline Rental costs laboratory (Norway) & 0.17 & 0.01 & Rental costs laboratory (Norway) & - & 0.01 \\
\hline Rental costs laboratory and office (The Netherlands) & 0.20 & 0.01 & & & \\
\hline Depreciation (laboratory equipment) & 0.09 & 0.02 & Depreciation (machinery. boat. installation) & 0.51 & 0.14 \\
\hline Total $\left(E U R \mathrm{~m}^{-2}\right)$ & 3.79 & 0.53 & Total $\left(E U R \mathrm{~m}^{-2}\right)$ & 3.88 & 1.72 \\
\hline Total (EUR kg ${ }^{-1}$ dry weight) & 2.53 & 0.27 & Total (EUR kg ${ }^{-1}$ dry weight) & 2.59 & 0.86 \\
\hline
\end{tabular}

Today, no industrial scale biorefinery exists to extract protein from seaweed in Norway. Therefore, in this study, we are assuming that the costs of refining soybean flour to SPC are similar to the costs of refining dry seaweed to SPP and take into account that SPC normally costs 2 to 2.5 times more to process than soybean flour (Berk 1992). We can thus infer that the cost of soybean flour is about $0.40 \mathrm{US} \$ \mathrm{~kg}^{-1}$, which implies that the costs of soybean flour is about $40 \%$ cheaper than that of dried seaweed and that SPP will cost about 2.8 times more than SPC (2.5 EUR kg $\left.{ }^{-1}\right)$. Assuming that the drying process and the biorefinery costs will increase linearly with increased production is a conservative approach, and therefore, the cost for SPP can probably be reduced further by scaling.

From Table 1, we see a rapid decline $(78 \%)$ in cost when scaling seaweed farms from 20 to 600 ha. Scaling processes are not linear due to the fact that costs are both variable and fixed, so we cannot observe the same scaling effects for the next 30-fold increase due to the Law of Diminishing Returns in Economics. To understand the cost implications for a largescale operation, we must extrapolate the quantity of SPP to large scale.

Several formulas can be used in various stages of designing plants in general (Tsagkari et al. 2016). Since SPP biorefineries have not yet been built, the accuracy of the estimates to use is in the "order of magnitude," as ANSI (American National Standards Institute) denotes it. One technique used for estimating the effects of scaling on cost data is the power law technique first proposed by Williams Jr (1947).
According to Tsagkari et al. (2016), it is frequently used due to its capability of extrapolating data from one scale to another. The calculation is expressed by Eq. 1:

$\frac{C_{1}}{C_{2}}=\left(\frac{S_{1}}{S_{2}}\right)^{p} * t$

where $C_{1}$ is the investment cost for providing a certain scale $\left(S_{1}\right)$. Similarly, $C_{2}$ is the investment cost for providing a certain scale $\left(S_{2}\right)$. This approach will give an investment estimate, which can be used to estimate depreciations. The operating costs and the total costs (depreciations plus operating costs) can then be estimated further. The factor $t$ is a correction factor for handling differences in date, location, pressures, temperatures, and materials of construction, which do not apply in our case so far. Thus, we set the correction factor $t$ to 1 . The exponent $p$, however, is important for our project because it directly impacts the effects of scaling on the costs.

Table 2 shows value ranges for common types of biorefineries. Due to the character of seaweed being something in between solids and liquids, we find a $p$ in the lower range of $0.7-0.9$ to be most appropriate. We use 0.75 in the calculations.

From Table 3, we can estimate that depreciation costs and other equipment-related costs constitute about $30 \%$ of operating costs for the crop seedling, cultivation, and harvesting part. This is likely to change as scale grows. Since the numbers are relatively smaller than the ones used for the biorefinery and they are unavailable at the time of our study, 
Table 2 Typical values of exponent $p$ for common biorefineries. Source: Tsagkari et al. (2016)

\begin{tabular}{|c|c|c|c|}
\hline$p$ & Biorefinery type & $\begin{array}{l}\text { Phase } \\
\text { type }\end{array}$ & $\begin{array}{l}\text { Cost items } \\
\text { (Free-On-Board; Incoterms, 2000) }\end{array}$ \\
\hline$>1.0$ & & & Piping \\
\hline $0.9-1.0$ & Seed crushing units & Solids & $\begin{array}{l}\text { Multiple fermenters or other equipment items, catalysts, } \\
\text { chemicals, civil works, construction }\end{array}$ \\
\hline $0.7-0.9$ & $\begin{array}{l}\text { Grains to bioethanol, lignocellulosic biomass-to-ethanol, renewable } \\
\text { diesel, biomass-to-ethanol (by gasification) }\end{array}$ & & Crushers, compressors, electrostatic precipitators \\
\hline $0.6-0.7$ & Oil to biodiesel & Liquids & Blowers, pumps, crystallizers, pressure vessels \\
\hline $0.3-0.6$ & & Gas & $\begin{array}{l}\text { Agitators, conveyors, dryers, filters, shell-tube heat } \\
\text { exchangers, jacketed reactors, horizontal tanks }\end{array}$ \\
\hline
\end{tabular}

the power law was used with the typical $p$ of 0.6 , a technique often called six tenth rule for rough estimates (Cheali et al. 2015).

The portion of investment costs are also likely to change since a large seaweed farm requires larger vessels and infrastructure, whereas the required manpower may be similar to smaller seaweed farms due to more industrial processes. Hence, $30 \%$ investment was estimated as too low for this magnitude of scale of a new industry known to be more capital intensive. An increase of $40 \%$ investment is therefore proposed. In addition, the vessel cost must be added and it requires 10 million EUR in investment depreciated over 10 years. Using multi-purpose vessels would be highly beneficial as they could fill other functions outside the seaweed harvesting season.

When it comes to estimating the cost structure of a large biorefinery, data are even more limited. As a proxy with similar order of magnitude, we will use the study from Haque et al. (2014) on biorefineries for converting switch grass feedstock to cellulosic ethanol as a reference. Haque et al. (2014) reported that the operations costs are $260 \mathrm{USS} \mathrm{m}^{-3}$ for a facility of handling $189 \mathrm{dam}^{3}$ year $^{-1}\left(189,000 \mathrm{~m}^{3}\right.$ year $\left.^{-1}\right)$ had an investment cost of 379 million US\$. Assuming 15 years depreciation, this converts to $133 \mathrm{US} \$ \mathrm{~m}^{-3}$ in depreciation. Thus, total costs are roughly $400 \mathrm{US} \$ \mathrm{~m}^{-3}$ out of which $33 \%$ is investment related. Annualized capital costs are a little higher than the $20 \%$ rule of thumb, used by Cheali et al. (2015). However, this technique is utilized in cases with very large scale. Hence, $30 \%$ investment for the refineries may be a realistic assumption.

Table 3 presents the confirmed production numbers from one of the pioneer seaweed farms in Norway, previously studied by Chapman et al. (2014), and extended here to include a small scale biorefinery to produce SPP. These data are used to estimate the cost in the right order of magnitude with results for the biorefinery as shown in lower part of Table 3 .

It is also important to note that our study considers that $1 \mathrm{~kg}$ SPP contains only $10 \%$ protein whereas SPC contains about

Table 3 Comparative cost analysis for conceptual study of producing SPP on a similar scale as SPC

\begin{tabular}{|c|c|c|c|c|c|}
\hline \multirow{2}{*}{$\begin{array}{l}\text { Crop seedling, cultivation and harvesting } \\
\text { Area } 1\end{array}$} & \multicolumn{2}{|c|}{ Hortimare scale } & \multirow{2}{*}{$\begin{array}{l}\text { Crop seedling, cultivation and harvesting } \\
\text { Area } 2\end{array}$} & \multicolumn{2}{|l|}{ Large scale } \\
\hline & 6000 & $\mathrm{~m}^{2}$ & & $12,500,000$ & $\mathrm{~m}^{2}$ \\
\hline Yield & 2.00 & $\mathrm{~kg} \mathrm{~m}^{-2}$ & Yield & 2.00 & $\mathrm{~kg} \mathrm{~m}^{-2}$ \\
\hline Scale 1 & 12,000 & $\mathrm{~kg}$ & Scale 2 & $25,000,000$ & $\mathrm{~kg}$ \\
\hline Investment cost to total costs 1 & $30 \%$ & & Investment cost to total costs 2 & $40 \%$ & \\
\hline Operating cost at scale 1 & 0.86 & EUR kg ${ }^{-1}$ & Operating cost at Scale 2 & 0.04 & EUR kg ${ }^{-1}$ \\
\hline Annual operating costs 1 & 10,320 & EUR year ${ }^{-1}$ & Annual operating costs 2 & $1,008,571$ & EUR year $^{-1}$ \\
\hline Investment costs 1 & 3096 & EUR year ${ }^{-1}$ & Investment costs 2 & 403,428 & EUR year $^{-1}$ \\
\hline Initial investment 1 & 30,960 & EUR & Initial investment 2 & $4,034,284$ & EUR \\
\hline Biorefinery & Hortim & & Biorefinery & Large scale & \\
\hline Scale 1 & 12,000 & $\mathrm{~kg}$ & Scale 2 & $25,000,000$ & $\mathrm{~kg}$ \\
\hline Investment cost to total costs 1 & $30 \%$ & & Investment cost to total costs 2 & $30 \%$ & \\
\hline Operating cost at scale 1 & 2.50 & EUR kg ${ }^{-1}$ & Operating cost at scale 2 & 0.37 & EUR kg ${ }^{-1}$ \\
\hline Annual operating costs 1 & 30,000 & EUR year ${ }^{-1}$ & Annual operating costs 2 & $9,251,035$ & EUR year $^{-1}$ \\
\hline Investment costs 1 & 9000 & EUR year ${ }^{-1}$ & Investment costs 2 & $2,775,311$ & EUR year $^{-1}$ \\
\hline Initial investment 1 & 90,000 & EUR & Initial investment 2 & $27,753,105$ & EUR \\
\hline Total cost & 3.36 & EUR kg ${ }^{-1}$ & Total cost & 0.41 & EUR kg ${ }^{-1}$ \\
\hline
\end{tabular}


60-64\%. At the same time, $1 \mathrm{~kg}$ protein from SPC costs about $1.8 \mathrm{US} \mathrm{kg}^{-1}$ or about $1.5 \mathrm{EUR} \mathrm{kg}^{-1}$. This conversion is based on the EUR/US\$ exchange rate in the DNB currency calculator $^{1}$ at the time of analysis (16 January 2018) which was 1.2226. Furthermore, SPP costs about 4.3 EUR kg ${ }^{-1}$ or more, which is 3 times more expensive than SPC. As a conclusion, SPP produced under the prerogatives of our study is not competitive against SPC as a protein source for fish feed on a cost basis even on a large, industrial scale. The competitiveness of seaweed biomass over soya biomass as a protein source for fish feed must therefore arise from the added value from other chemical compounds in seaweed.

\section{Value of SPP compared with SPC}

The major cost driver in feed production is the price of raw material (Ernst and Young 2017). Marine-sourced ingredients such as fish meal or fish oil are commodities with fluctuating and seasonal supply patterns, which, combined with a fastgrowing fish-farming industry which demands more feed, has resulted in fluctuating and increasing prices. Although substitutes such as SPC experience price volatility, prices (and quality) are far more stable in comparison to marinesourced ingredients.

Micro-ingredients inclusion (in feed) is marginal compared with macro-ingredients (e.g., proteins, fats) but are crucial in feed formulas. From Table 4, we find that some microingredients are highly valuable and it is interesting that many of these could also be key biproducts in a SPP production. Yet, to understand the way these seaweed biproducts, their future value, the quantities that can be extracted and related production costs needs to be identified. As no data are easily available today, neither costs nor outcome was included in our economic model but represents a potential uncaptured upside to our modeling.

In Table 5, we present some market value estimates from 2011 that were used when calculating the likely market value of the SPP. We focused on two products already on the market-laminaran and mannitol—as value differentiating chemical compounds in the SPP (in addition to protein), the value calculations are shown in Table 6 . To make it comparable to SPC, we have scaled the unit calculation to $6.0 \mathrm{~kg}$, since $6.0 \mathrm{~kg}$ SPP contains the same amount of protein as $1 \mathrm{~kg}$ SPC. This gives a production cost of $2.46 \mathrm{EUR}$. In these $6.0 \mathrm{~kg}$ of SPP, there are $0.8 \mathrm{~kg}$ of laminaran and $0.7 \mathrm{~kg}$ of mannitol. Given the price levels in Table 5, this gives a value of 0.29 EUR for the laminaran and 1.08 EUR for the mannitol, respectively, as shown in Table 6.

Including the value of proteins, this gives a value of 1.91 EUR produced at a cost of 2.46 EUR. This gives a return on

\footnotetext{
${ }^{1}$ See https://www.dnb.no/bedrift/markets/valuta-renter/kalkulator/ valutakalkulator.html
}

Table 4 Micro-ingredient market prices per February 2018. Source: Storaa (2018)

\begin{tabular}{lc}
\hline Ingredient & Price $\left(\mathrm{EUR} \mathrm{kg}^{-1}\right)$ \\
\hline A-500 & 155.0 \\
B1-vit. & 64.0 \\
B2-vit. & 55.0 \\
B6 & 58.0 \\
Biotin & 19.0 \\
Calpan & 50.0 \\
D3-500 & 49.0 \\
E-50\% & 12.0 \\
Folin & 40.0 \\
K3-vit. & 17.7 \\
Copper & 1.9 \\
Lysin HCL & 1.3 \\
Lysin sulfate $70 \%$ & 0.7 \\
Magn. 50\% & 0.3 \\
Manganese & 0.8 \\
MCP & 0.4 \\
Methionin & 2.4 \\
MGP & 0.5 \\
Niacin & 6.0 \\
Threonin & 1.4 \\
Tryptophan & 14.0 \\
Valin & 4.9 \\
Zinc & 1.8 \\
\hline & \\
&
\end{tabular}

sales (ROS) of $-29 \%$, which means negative profitability. For SPC, the ROS is about $0 \%$. Hence, SPP is at a disadvantage but this is not the conclusion per se because other components must be considered including the uncertainty of all the data used in the modeling.

We investigated uncertainty impacts the results using the approach described in Emblemsvåg (2003). To identify the drivers of uncertainty, we ran Monte Carlo simulations with 50,000 trials using $\pm 10 \%$ triangular uncertainty distributions for all the variables in the model. When it comes to estimating the impact of the uncertainty, we used $\pm 20 \%$ triangular uncertainty distributions. This significant amount of uncertainty is due to all the sources of uncertainty in the modeling concerning both the available data and the crudeness of the power law.

The results from these simulations demonstrate that in the alternative where SPP is determined solely by its protein content (alternative 1, which consists of the "protein" line in Table 6), the production will currently be unprofitable. However, when the SPP price includes the three different ingredients, as indicated in Table 6 , the results become far more promising as shown in Fig. 2.

As mentioned, the deterministic ROS is $-29 \%$, but from the uncertainty distribution in Fig. 2, we see that this approach 
Table 5 Components from brown macroalgae: S. latissima and L. digitata and resulting market value after biorefinery. Source: Holdt and Kraan (2011)

\begin{tabular}{llllr}
\hline Component & Application & Market value (EUR t $\left.{ }^{-1}\right)$ & Percent in kelp dw & Value in dry kelp (EUR t $\left.^{-1}\right)$ \\
\hline Protein & Fish feed & 1400 & 15 & 210 \\
Mannitol & Food & 1500 & 12 & 180 \\
Phycocolloids & Food & 3000 & 23 & 690 \\
Laminaran & Food. pharmacy & 350 & 14 & 49 \\
Fatty acids (PUFA) & Food & 1250 & 4 & 50 \\
Polyfenols & Anti-oxidant & 20,000 & 0.5 & 100 \\
Iodine & Food. pharmacy & 25,000 & 0.4 & 100 \\
Fucoxanthin & Pigment. & 200,000 & 0.05 & 100 \\
Fucoidan & antioxidant & 8000 & 5 & 400 \\
\hline
\end{tabular}

has a realistic chance of becoming profitable. More specifically, the probability of going break-even or better, i.e., a positive ROS, is between 25 and $30 \%$. Besides, if we deterministically test the model with an assumption that the scale of the biorefinery is larger than $65,000 \mathrm{t}$ per year of frozen seaweed, the ROS $>0.9 \%$ or close to $0 \%$. This implies that the deterministic break-even point is about 65,000 $\mathrm{t}$ per year of frozen seaweed for a seaweed biorefinery. It is important to note that the seaweed will lose some weight during harvesting as water will run off towards the process of freezing the seaweed. The amount is unclear at the moment since neither ship design nor technologies are solved. Hence, the aforementioned 65,000 t cannot be interpreted as wet weight.

The driving factors of these results can be obtained from the analysis of variance (ANOVA) from the Monte Carlo simulation results. Two large, dominant factors of the competitiveness of the SPP were identified: the protein content of the SPC and the scaling effect of the facility. The protein content of SPC is important because the economic difference is partly driven by the difference in protein content between SPC and SPP.

More knowledge about factors influencing the protein content (Sharma et al. 2018) of seaweed is necessary for an increased protein yield, while upscaling of the farm area is absolutely possible to influence. Based on the high-value compounds presented in Table 5, the SPP can become competitive against SPC from a scale of $65,000 \mathrm{t}$ per year of frozen

Table 6 The value model for SPP

\begin{tabular}{llllll}
\hline $\begin{array}{l}\text { Chemical } \\
\text { composition } \\
\text { of SPP }\end{array}$ & $\begin{array}{l}\text { Fraction } \\
\text { in dry } \\
\text { weight }\end{array}$ & $\begin{array}{l}\text { Component- } \\
\text { value (EUR } \\
\mathrm{kg}^{-1} \text { ) }\end{array}$ & $\begin{array}{l}\text { Mass in } \\
\text { 6 kg SPP } \\
(\mathrm{kg})\end{array}$ & $\begin{array}{l}\text { Cost } \\
6 \mathrm{~kg} \\
\text { SPP } \\
\text { (EUR) }\end{array}$ & $\begin{array}{l}\text { Value in } \\
\text { 6 kg SPP } \\
\text { (EUR) }\end{array}$ \\
\hline SPP & $100 \%$ & & 6.00 & 2.46 & \\
Protein & $10 \%$ & 0.90 & 0.60 & & 0.54 \\
Laminaran & $14 \%$ & 0.35 & 0.84 & & 0.29 \\
Mannitol & $12 \%$ & 1.50 & 0.72 & & 1.08 \\
Sum & $36 \%$ & & & 2.46 & 1.91 \\
\hline
\end{tabular}

seaweed and above. Furthermore, increasing the yield of the protein extraction process from the seaweed could also be a limiting factor at present, and a factor that could be improved in the future.

\section{Discussion-how SPP can outcompete SPC and the research implications}

From our analyses, we find that the key determinant factors for SPP to compete against SPC include:

1. Scale of the biorefinery is crucial. Sufficient supply of seaweed needs to be secured to ensure the biorefinery can produce at full, or close to full, capacity. The biorefinery should have an annual capacity of at least $65,000 \mathrm{t}$ of frozen seaweed.

2. Large scale is required for offshore seaweed farms or IMTA sites from where the seaweed will be gathered by large, multipurpose vessels with sufficient freezing capacity. The frozen seaweed will then be transported to the biorefinery and stored to secure a 24/7 operation.

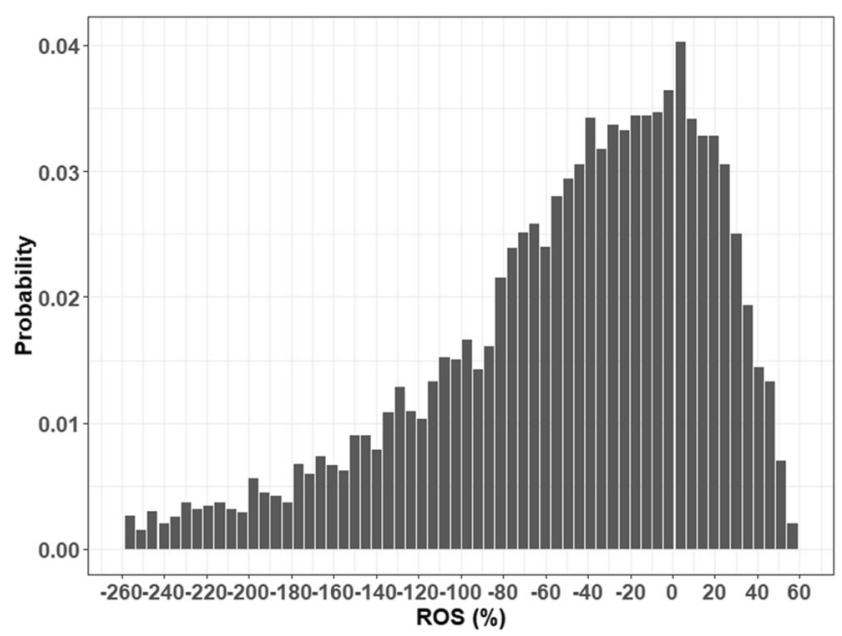

Fig. 2 ROS (\%) for SPP being sold as indicated in Table 6, i.e., alternative 2 
3. The prices and amounts of extracted laminaran and mannitol during the biorefinery processes are crucial for the economic results.

4. The investment costs for the large-scale biorefinery are also important. A carefully designed process for extracting the right fractions in the most cost-effective manner is crucial.

5. The higher the protein content of the SPP, the more competitive SPP will be against SPC.

These key factors will be issues to address in future research. Much research is concerning dried seaweed or seaweed meal, and such approaches can be interesting for highend usage. However, due to costs, it has limited potential for industrial scale usage such as being used as ingredient for fish feed. Research should focus more on providing a SPP that can outcompete SPC and focus on building and operating largescale biorefineries that would extract high-value compounds at a high yield.

\section{Closure and future work}

Under current economic conditions and those of the foreseeable future, SPC seems to have a stronger competitive position to SPP even if we solve the issues addressed in "Strategic analysis of SPP versus SPC," although our study offers alternative avenues for research that can alter this conclusion.

A key driver could be as The Economist (2017) notes: "The problem with afforestation and BECCS is that the plants involved need a huge amount of land. The area estimated ranges from 3.2 million square kilometers (roughly the size of India) to as much as 9.7 million square kilometers (roughly the size of Canada). That is the equivalent of between $23 \%$ and $68 \%$ of the world's arable land." Hence, the land used for growing SPC today may have to be used for other purposes, at least a major portion of it. This may result in regulatory changes that will change the entire competitive landscape for SPP versus SPC. Therefore, to bring forth changes more rapidly, governments should perhaps persuade the fish feed industry to implement the change for example by rerouting the funds spent at reducing deforestation in Brazil and/or through regulations on the account of the environmental performance of the ingredients used in fish feed.

Such incentives may bring forward seaweed in the short term and contribute in the scale-up of its production volume. Finally, close collaboration between research institutions and industry to increase the quantity and pace of knowledge transfer would also be fundamental in rapidly developing an industrial scale seaweed aquaculture in Norway. With a lower environmental footprint, SPP ought to become a more attractive source of protein for the fish feed industry going forward.
Acknowledgments Open Access funding provided by NTNU Norwegian University of Science and Technology (incl St. Olavs Hospital - Trondheim University Hospital). This work is part of the PROMAC research project ("Energy efficient processing of macroalgae in blue-green value chains") financed by The Research Council of Norway (grant number 244244) under the program NFR-HAVBRUK2. The authors would like to sincerely thank Pierrick Stévant (Møreforsking Ålesund AS), Freek van den Heuvel (Hortimare), Inga Marie Aasen (SINTEF Industry) and Annik Magerholm Fet (NTNU) for advice and sharing their knowledge. We would also like to thank our reviewers for critically reviewing the initial manuscript. This improved the paper significantly.

Open Access This article is licensed under a Creative Commons Attribution 4.0 International License, which permits use, sharing, adaptation, distribution and reproduction in any medium or format, as long as you give appropriate credit to the original author(s) and the source, provide a link to the Creative Commons licence, and indicate if changes were made. The images or other third party material in this article are included in the article's Creative Commons licence, unless indicated otherwise in a credit line to the material. If material is not included in the article's Creative Commons licence and your intended use is not permitted by statutory regulation or exceeds the permitted use, you will need to obtain permission directly from the copyright holder. To view a copy of this licence, visit http://creativecommons.org/licenses/by/4.0/.

\section{References}

Aas TS, Ytrestøyl T, Åsgård T (2019) Utilization of feed resources in the production of Atlantic salmon (Salmo salar) in Norway: an update for 2016. Aquaculture Rep 15. https://doi.org/10.1016/j.aqrep.2019. 100216

Aasen IM (2018) Personal communication during ProMac project meetings.

Beltran AM, Chiantore M, Pecorino D, Corner RA, Ferreira JG, Cò R, Fanciulli L, Guinée JB (2017) Accounting for inventory data and methodological choice uncertainty in a comparative life cycle assessment: the case of integrated multi-trophic aquaculture in an offshore Mediterranean enterprise. Int J Life Cycle Assess. https://doi. org/10.1007/s11367-017-1363-2

Berk Z (1992) Technology of production of edible flours and protein products from soybeans. FAO Agricultural Services Bulletin. FAO Corporate Docment Repository, Rome

Boffey D (2019) Norway halts Amazon fund donation in dispute with Brazil: International concerns grow over deforestation surge since Jair Bolsonaro took power. The Guardian. https://www.theguardian. com/world/2019/aug/16/norway-halts-amazon-fund-donationdispute-brazil-deforestation-jair-bolsonaro\#: :text=Norway\% 20 has $\% 20$ followed $\% 20$ Germany $\% 20$ in, from $\% 20$ the $\%$ 20country's\%20rightwing\%20president. Accessed 16 August.

Broch OJ, Alver MO, Bekkby T, Gundersen H, Forbord S, Handå A, Skjermo J, Hancke K (2019) The kelp cultivation potential in coastal and offshore regions of Norway. Front Mar Sci 5:529

Broch OJ, Ellingsen I, Forbord S, Wang X, Volent Z, Alver M, Handå A, Andresen K, Slagstad D, Reitan K, Olsen Y, Skjermo J (2013) Modelling the cultivation and bioremediation potential of the kelp Saccharina latissima in close proximity to an exposed salmon farm in Norway. Aquacult Environ Interact 4:187-206

Buck BH, Troell M, Krause G, Angel D, Grote B, Chopin T (2018) State of the art and challenges for multi-trophic offshore aquaculture. Front Mar Sci 5:165

Buck BH, Langan R (2017) Epilogue - pathways towards sustainable ocean food production. In: Bela HB, Langan R (eds) Aquaculture 
perspective of multi-use sites in the open ocean. Springer, Cham, pp 395-404

Castanheira ÉG, Freire F (2013) Greenhouse gas assessment of soybean production: implications of land use change and different cultivation systems. J Clean Prod 54:49-60

Chapman A, Stévant P, Schipper J, Kråkås Ø, Aspøy B, Stavland A (2014) Markendsvurderinger for bærekreftig algedyrking i Integrert Multitrofisk Akvakultur (IMTA)-anlegg. Møreforskning, Alesund

Cheali P, Gernaey KV, Sin G (2015) Uncertainties in early-stage capital cost estimation of process design - a case study on biorefinery design. Front Energy Res 3:1-13

Directorate of Fisheries (2020) Feed 1991 - 2019 https://www.fiskeridir. no/English/Aquaculture/Statistics/Others. Accessed $23^{\text {rd }}$ April.

Emblemsvåg J (2003) Life-cycle costing: using activity-based costing and Monte Carlo methods to manage future costs and risks. Wiley, Hoboken

Enriquez S, Duarte CM, Sand-Jensen K (1993) Patterns in decomposition rates among photosynthetic organisms: the importance of detritus $\mathrm{C}$ :N :P content. Oecologia 94:457-471

Ernst \& Young (2017) The Norwegian aquaculture analysis 2016. Ernst $\&$ Young.

FAO (2019a) The FAO Fishery and Aquaculture Statistics Yearbook 2017; Dataset Global Aquaculture Production 1950-2017. Food and Agriculture Organization of the United Nations, Rome

FAO (2019b) General Standard for Soy Protein Products - CXS 1751989. Food and Agriculture Organization (FAO) of the United Nations and World Health Organization (WHO), Rome

Handå A, Forbord S, Wang X, Broch OJ, Dahle SW, Størseth TR, Reitan KI, Olsen Y, Skjermo J (2013) Seasonal- and depth-dependent growth of cultivated kelp (Saccharina latissima) in close proximity to salmon (Salmo salar) aquaculture in Norway. Aquaculture 414415:191-201

Haque M, Epplin FM, Biermacher JT, Holcomb RB, Kenkel PL (2014) Marginal cost of delivering switchgrass feedstock and producing cellulosic ethanol at multiple biorefineries. Biomass Bioenergy 66: 308-319

Harper A (1981) Amino Acid Scoring Patterns. Joint FAO/WHO/UNU Expert Consultation on Energy and Protein Requirements, Rome

Holdt SL, Kraan S (2011) Bioactive compounds in seaweed: functional food applications and legislation. J Appl Phycol 23:543-597

Holmer M (2010) Environmental issues of fish farming in offshore waters: perspectives. concerns and research needs. Aquacult Environ Interact 1:57-70

Holtermann C, Pettersen R (2019) Personal communication on October 10th.

Lum KK, Kim J, Lei XG (2013) Dual potential of microalgae as a sustainable biofuel feedstock and animal feed. J Animal Sci Biotechnol 4.53

Lundeberg H (2018) Soya i norsk fôr - Forbruk og arealbeslag (in Norwegian). Framtiden i våre hender, Oslo

Lundeberg H, Grønlund AL (2017) Fra brasiliansk jord til norske middagsbord: En rapport om soya i norsk laksefôr (in Norwegian). Framtiden i våre hender og Regnskogfondet.
Mæhre HK, Malde MK, Eilertsen K-E, Elvevolla EO (2014) Characterization of protein. lipid and mineral contents in common Norwegian seaweeds and evaluation of their potential as food and feed. J Sci Food Ag 94:3281-3290

Polprasert C (2007) Organic waste recycling: technology and management. IWA Publishing, London

Porter ME (1985) Competitive advantage: creating and sustaining superior performance. The Free Press, New York

Raucci GS, Moreira CS, Alves PA, Mello FFC, Frazão LD, Cerri CEP, Cerri CC (2015) Greenhouse gas assessment of Brazilian soybean production: a case study of Mato Grosso State. J Clean Prod 96:418 425

Seghetta M, Romeo D, D’Este M, Alvarado-Morales M, Angelidaki I, Bastianoni S, Thomsen M (2017) Seaweed as innovative feedstock for energy and feed - evaluating the impacts through a Life Cycle Assessment. J Clean Prod 150:1-15

Sharma S, Neves L, Funderud J, Mydland LT, Øverland M, Horna SJ (2018) Seasonal and depth variations in the chemical composition of cultivated Saccharina latissima. Algal Res 32:107-112

Siegle L (2009) Is eating soya causing damage to the planet? The Guardian.

Snyder H (2019) Literature review as a research methodology: an overview and guidelines. J Bus Res 104:333-339

Storaa KA (2018) Personal communication on February $28^{\text {th }}$.

Statistics Norway (2018) Aquaculture. https://www.ssb.no/en/jord-skogjakt-og-fiskeri/statistikker/fiskeoppdrett. Accessed 23 April 2020.

Stévant P, Rebours C, Chapman A (2017a) Seaweed aquaculture in Norway: recent industrial developments and future perspectives. Aquac Int 25:1373-1390

Stévant P, Marfaing H, Rustad T, Sandbakken I, Fleurence J, Chapman A (2017b) Nutritional value of the kelps Alaria esculenta and Saccharina latissima and effects of short-term storage on biomass quality. J Appl Phycol 29:2417-2426

Stévant P, Marfaing H, Duinker A, Fleurence J, Rustad T, Sandbakken I, Chapman A (2018) Biomass soaking treatments to reduce potentially undesirable compounds in the edible seaweeds sugar kelp (Saccharina latissima) and winged kelp (Alaria esculenta) and health risk estimation for human consumption. J Appl Phycol 30: 2047-2060

The Economist (2017) Briefing; Combating climate change. The Economist. November 18th. 19-21.

Tsagkari M, Couturier J-L, Kokossis A, Dubois J-L (2016) Early-stage capital cost estimation of biorefinery processes: a comparative study of heuristic techniques. ChemSusChem 9:2284-2297

Williams R Jr (1947) Six-tenths factor aids in approximating costs. Chem Eng 54:124-125

Ytrestøyl T, Aas TS, Åsgård T (2015) Utilisation of feed resources in production of Atlantic salmon (Salmo salar) in Norway. Aquaculture 448:365-374

Publisher's note Springer Nature remains neutral with regard to jurisdictional claims in published maps and institutional affiliations. 